\title{
WOMAN IMAGE IN ENGLAND IN 19TH CENTURY IN JANE AUSTEN'S SENSE AND SENSIBILITY
}

\author{
Ririn Tasumbey
}

\begin{abstract}
The purpose of this study is to reveal about womens' image in England in 19th century especially the existance of women that lived during Austen's era at the time. In analyzing this study the writer used qualitative research design which is the data collected in form of words rather than numbers. The data collected in this research are from two sources; primary and secondary. The primary source is from the novel itself and the secondary sources are from internet, and some other books. The datas are analyzed by using mimetic approach. The result of the study shows that fearness, dissapointment, unhappiness, and even arrogance are parts of life of some women at that time. They have no choice to choose a better life. England adopted Primogeniture as a basic of inherit the wealth to the children. This one is a reason why woman in society is placed lower rather than man. Man hold the authorithy in many aspects such as social, politics, and economic. However, girls were not gaining any noticeably easier access to legal rights or professional opportunities at this time. There was an over-riding assumption that men and women were different in natural capabilities. Consequently, both men and women ought to accept distinct social roles, marked out along gender lines, where women were denied equality of opportunity in areas such as education, business and action. Girls were praised for being submissive, modest, pure and domesticated. The qualities of being independently-minded, studious or talented were seldom regarded as feminine attractions. In the other hand, there was still few women who could face the problem toughly.
\end{abstract}

Keywords: Woman, Late Ninetenth Century, Mimetic Approach, social roles

\section{INTRODUCTION}

Novel as one of literary work which is presented about life, like social life, love story, feeling, passion and motives by which are governed and impaled with their joys and sorrow, then struggle, success, and failing. In this study the writer chooses Sense And Sensibility as one of literary works written by Jane Austen. The story of this novel represented about how the womens' image revealed in 19th century in England. Woman is adult female human being (Oxford Lerner's Pocket Dictionary 2008:512) and image is impression, that a person, company, product etc gives to the public (Oxford Lerner's Pocket 2008:220). It 
can be summaried up that woman image is the impresion that female gives to public. The woman image must be seen on how do they react in the society or how do they behave to show their image.

In Austen's era exactly in I9th century, women were expected to be biddable, submissive, pure, domesticated and modest. Beside it, they also were insisted for being talented in playing instrument or singing, and also being independently-minded as regarded of the attractions of female. There was different opportunity between women and men at the time, for example of unequal opportunity between the sexes concerned physical relationships before marriage. In England the inheritance arrangement was called primogeniture, and it was the established legal system at that time. Nowadays, women play their roles, and fuction as similar as men do. On the other hand woman in England in 19th century had no choice or even chance to play what they have to play. It is caused of the difference image between man and woman. Consequently woman defined like a weaker who always being able to follow the rule at the time. Furthermore, for women who had a good life such as have lots of money, property or wealth, they can do everything they want eventough sometimes it must be hurting someone else. Thus some women not only live in a pain life, but also stressfull condition. Some of them decide to be strong but the other could be sick to face that problem.

The novel Sense and Sensibility talks about the Dashwood family, Mrs. Dashwood, Elinor, Marianne, and Margareth who lived suffering because they did not get any inheritance by their father's death. Womens' image had been created as a lower status in the society at the time since they had nothing for their living, the main reason of this case caused by the law of promogeniture which limited the right of women. So many problems come and almost always being part of them. Lots of women lived undersestimately, but in meantime there were also some of women who lived selfishly and arrogance just because of the status that they already installed in the society. At the time, not only men who threated women badly but also women who did so. The purpose of the study is to reveal womens' image in England in 19th century in Sense And Sensibility

\section{Womens' Image In England In 19th Century}

The trend in the belief of feminine inferiority was halted as women effectively managed organizations not directly related to the family. To alleviate the fears of men that their wives were concentrating on issues unrelated to the family, piety did not keep a wife from her proper sphere. Meetings could be held in the home. Young children could be brought along the same way they would be when visiting friends. The lady of the house would demonstrate her domestic skills by cleaning the house before her guests arrived and by making sure they had something to accompany the tea which could be served during 
a meeting. It was believed that a woman's gentler nature better suited her to piety and charity. The number of women that ministers found among their congregations was great. The virtuous character of the deceased gave example of how religion could bring pleasure to the mind and be the controlling power over the conduct of life. Furthermore, other women could take example from Mrs. Thompson who did not regard the duties of domestic life as beneath the Christian notice of character and professed it was not inconsistent with her obligations to God and the Savior. Women may have found peace from the corruption of the world through religion. It also provided an outlet for the personal trials which women were forced to confront from day to day. Men could use their job to take their mind off of trouble at home, but women's job was at home. The death of a child was one example of a woman's involvement with religion. Religion instructed to love God before all others. The mother was often torn between the belief that her piety had provided salvation for her child and the thought that a moment of impiety on her part may have invoked God's wrath. Women were expected to be pure and magazines provided sufficient fear of the dangers of impurity. But, only women were coached directly on remaining pure. Men were advised what to do to get back on the track once they had strayed. They were first advised about the importance of their desires and satisfaction. The fact that it was basic to educate a woman on keeping her husband's heart as pure as possible indicates that women expected a high rate of activity on the part of the man. A man of the period was expected to respect purity. If he made any overtures and a woman stopped him from violating her purity, he was expected to be grateful to her. The implication was that he would think much more of a woman who saved him from himself than he would of a woman who allowed him to ruin her purity. A woman's wisdom in these matters of delicacy was her means of influence over the nature of man. Women, through religion and purity were helping others. Being self? sacrificing by nature, they could only damage their own character by asking more of themselves. Women were taught that to be true, they were required to submerge their own talents to work for their husbands. It was totally acceptable for a wife to complement her husband by paying lip service to him. (http://www.teachushistory.org/detocqueville-visit-united-states/articles/ early-19th-century-attitudes-toward-women-their-roles)

\section{The Law of Primogeniture}

Primogeniture is a system of inheritance where all property is handed down to the first-born son. During the Middle Ages in Western Europe, the oldest son the Lord of the Manor would become the Lord himself upon the death of his father, much in the same way that the oldest son of a king would gain the crown. The younger sons would have to find other careers. The military was an option for many sons. A knight began his training as a young boy and advanced to the rank of squire at about the age of fifteen. When the overlord 
considered the young squire worthy, he was proclaimed a knight, and was entitled to the honorific title "Sir." Knights were expected to be chivalrous. Chivalry was a set of rules for honorable behavior followed by the knights. The term chivalry now refers to aristocratic display and public ceremony rather than good manners. A third option was to acquire a trade. There were no trade schools in the Middle Ages. A father would pay a master to teach his son a trade. The boy would become an apprentice and often live with the family of the master tradesman. After a period of about seven years, the boy became a journeyman. He could now work in his trade and be paid for his work. If a journeyman were an expert in his trade, he might create a masterpiece and become a master himself, able to employ apprentices of his own. A young woman might look toward marriage in her future. A dowry was a present of money, goods, or sometimes land given by a bride's father to her husband. The dowry, however, was for his use, not hers. A dowry was thought to make a young girl more attractive to a potential husband. A large dowry might make it possible for a young lady to attract a rich landholder. Many girls entered the clergy as nuns, while others worked at servants at the manor house.(http://www.mrdowling.com/703-primogeniture.html)

\section{9th Century England Social Hierarchy}

Early in the nineteenth century the labels "working classes" and "middle classes" were already coming into common usage. The old hereditary aristocracy, reinforced by the new gentry who owed their success to commerce, industry, and the professions, evolved into an "upper class" (its consciousness formed in large part by the Public Schools and Universities) which tenaciously maintained control over the political system, depriving not only the working classes but the middle classes of a voice in the political process. The increasingly powerful (and class conscious) middle classes, however, undertook organized agitation to remedy this situation: the passage of the Reform Act of 1832 and the abolition of the Corn Laws in 1846 were intimations of the extent to which they would ultimately be successful. The working classes, however, remained shut out from the political process, and became increasingly hostile not only to the aristocracy but to the middle classes as well. As the Industrial Revolution progressed there was further social stratification. Capitalists, for example, employed industrial workers who were one component of the working classes (each class included a wide range of occupations of varying status and income; there was a large gap, for example, between skilled and unskilled labor), but beneath the industrial workers was a submerged "under class" - contemporaries referred to them as the "sunken people" - -- which lived in poverty. In mid-century skilled workers had acquired enough power to enable them to establish Trade Unions (Socialism became an increasingly important political force) which they used to further improve their status, while unskilled workers and the underclass beneath them remained much more susceptible to exploitation, and were 
therefore exploited. This basic hierarchical structure (presented here in highly oversimplified form), comprising the "upper classes," the "middle classes," the "Working Classes" (with skilled laborers at one extreme and unskilled at the other), and the impoverished "Under Class," remained relatively stable despite periodic (and frequently violent) upheavals, and despite the Marxist view of the inevitability of class conflict, at least until the outbreak of World War I. A modified class structure clearly remains in existence today.( http://www. victorianweb.org/history/Class.html)

\section{Woman in the 19th Century}

Scholarly analysis of nineteenth-century women has included examination of gender roles and resistance on either side of the Atlantic, most often focusing on differences and similarities between the lives of women in the United States, England, and France. While the majority of these studies have concentrated on how white, middle-class women reacted to their assigned domestic or private sphere in the nineteenth century, there has also been interest in the dynamics of gender roles and societal expectations in minority and lowerclass communities. Although these studies can be complementary, they also highlight the difficulty of making generalizations about the lives of women from different cultural, racial, economic, and religious backgrounds in a century of steady change. Where generalizations can be made, however, "the woman question," as it was called in debates of the time, has been seen as a tendency to define the role of women in terms of private domesticity. Most often, depictions of the lives of nineteenth-century women, whether European or American, rich or poor, are portrayed in negative terms, concentrating on their limited sphere of influence compared to that of men from similar backgrounds. In some cases, however, the private sphere of nineteenth-century women had arguably more positive images, defining woman as the more morally refined of the two sexes and therefore the guardian of morality and social cohesion. Women were able to use this more positive image as a means for demanding access to public arenas long denied them, by publicly emphasizing and asserting the need for and benefits of a more "civilized" and "genteel" influence in politics, art, and education. The same societal transformations that were largely responsible for women's status being defined in terms of domesticity and morality also worked to provoke gender consciousness and reform as the roles assigned women became increasingly at odds with social reality. Women on both sides of the Atlantic, including Angelina and Sarah Grimké, Sarah Josepha Hale, Charlotte Brontë, George Eliot, Elizabeth Gaskell, and Frances Power Cobbe, both expressed and influenced the age's expectations for women. Through their novels, letters, essays, articles, pamphlets, and speeches these and other nineteenth-century women portrayed the often conflicting expectations imposed on them by society. These women, along with others, expressed sentiments of countless women who were unable to 
speak, and brought attention and support to their concerns. Modern critical analyses often focus on the methods used by women to advance their cause while still maintaining their delicate balance of propriety and feminine appeal by not "threatening" men, or the family unit. (http://www.enotes.com/topics/feminism/critical-essays/women-19th-century)

\section{METHOD}

The qualitative research is applied in this study. the datas are taken in the forms of words. In conducting this research the writer collects some sources, which are related to the topic she has chosen. There are two kinds on sources used, primary and secondary sources. The primary source is the novel itself. The secondary source consists of facts and opinions outside the work itself, such as dictionary, internet, encyclopedia, books. In analysis the data, the writer used mimetic approach that concerned with the use of history of England in 19th century as Abrams stated that Mimetic approach views the literary works as imitation, reflection or representation of the world and human life, and primary criterion applied to a work is that of the truth of its representation of the subject matter that is represent (40. The historical and cultural context of England at the time, such as primogeniture, or even about womens' existance are considered in the process of analysis.

\section{FINDINGS}

In England in 19th century, womens' life were different with man. Woman had very limit right and also roles in the society, while man had lots of it. In fact, woman did do domesticated job at the house. They were expected to be a good wife and also good mother, took care the children, cleaned the house, and fulfilled everything that ought to be filled in the family life. Their property rights was also influenced by their husband's consent, as P. K. Das states;

In Medieval England of the property rights of women depended upon their marital status. Common law governed the married women's property rights which required that, the property, which woman took in a marriage or acquired later on, be legally absorbed by their husbands and likely no will or any other disposal of property were made without the consent of husband.(Property Right Of Women And Daughters, 15)

Quotation above explains that women right in England at the time must be managed by their husbands. They did not have any chance to make a will of property, because since they had already married, all of the fortune, money, wealth, or property were owned by her husband and she needed such an agreement of her husband to take that property. Womens' life were controlled by their husbands and also their existance were covered by them. So it could be said that women lived in a very limit world at the time. 


\section{Primogeniture Limited The Right of Women}

In England there was a common law that already being a bacic rule to inherit the wealth in the family. It was called primogeniture. Amy Louise Erickson states;

The best aspects of the law respecting women and property are the common law doctrines of converture in marriage and primogeniture in inheritance. Historians, lawyers, social scientists and literary critics all emphasize these doctrines. It is widely assumed that only landed families cared about property at all. They traced wealth from father to eldest son, while daughters were married off for familial interest. Marriage settlements were between the bride's father and the groom of his father, women not participating in the arragements. (Women And Property, 5)

The above citation explains that primogeniture is the right by law or custom, of the firstborn child to inherit the family estate, in preference to siblings. In the absence of children, inheritance passed to collateral relatives, usually males, in order of seniority of their lines of descent. The eligible descendants of deceased elder siblings take precedence over living younger siblings, such that inheritance is settled in the manner of a depth-first search. Thus in the family woman did not have any chance to inherit their father's bequest. This culture is one of england culture that also happened on The Dashwood Family.

"By a former marriage, Mr. Henry Dashwood had one son: by his present lady, three daughters. The son, a steady respectable young man, was amply provided for by the fortune of his mother, which had been large, and half of which devolved on him on his coming of age. By his own marriage, likewise, which happened soon afterwards, he added to his wealth". (Austen,2)

The quotations above shows us that in Austen's era, primogeniture is also part of law that should be followed by the society at the time. The story begins with Mr. Henry's son; John Dashwood who received fortune from his mother and he is completely secure to live with his son and his selfish wife Fanny Ferrars. Because of first born and the only child of Mr.Henry ex wife, John got all of the property from his mother. By this situation we may see that man is a primary individual who can inherit the wealth of their parents. They have authority to have everything of their parents including money, property, wealth, etc. They play roles widely rather than woman. In any case, if a man had already had authority to manage everything, he for sure can do whatever he wants. In fact, they could do something good but sometimes they perhaps do a bad thing.

"The old gentleman died; his will was read, and like almost every other will, gave as much disappointment as pleasure. He was neither so unjust, nor so ungrateful, as to leave his estate from his nephew;... Mr. Dashwood had wished for it more for the sake of his wife and daughters that for himself or his son;-but to his son, and his son's son, a child of 
four years old, it was secured, in such a way, as to leave to himself no power of prividing for those who were most dear to him...” (Austen,2)

Austen keeps prooving to us that primogeniture is very dominant in England in 19th century. In the story of her novel, she seems want to put infront that woman roles or rights is limited by that law. Furthermore, eventhough a daughter needs the wealth more than man, they do not have any strength to resist this law. The last owner of The estate of Sussex is Mr. Henry Dashwood's uncle who did not marry and did not have any sons or daughters. He lived with his nephew Mr. Henry Dashwood and his families. Mr. Dashwood gave his wealth to Mr. Henry's grandson to receive all of the wealth. Mr. Henry hoped that it will given to him but in fact it won't.

"His son was sent for as soon as his danger was known, and to him Mr. Dashwood recommended, with all the strength and urgency which illness could command, the interest of his mother-in-law and sisters..."

(Austen,2)

While Mr. Henry died, all of his wealth also is given to his first son from his first marriage. Actually, Mr. Henry cares so much about his daughters and wife future, but there is no choice for him to herit his wealth to them. It caused of the primogeniture law. He is kinda living in a dilema world, he has to give the wealth to someone that already been rich, rather than to his wife and daughters that will have nothing after he died. In conclusion, primogeniture almost influenced all aspects of woman and man life. The wealth is purposed primarily to a son rather than a daugther. Probably true, if a father is sometimes care about his daughters and wife future. Deep inside his heart, he wants to give the wealth to them, but in the other hand he has to follow the rule. Primogeniture manages man and woman images. Man seems has lots of roles while they are inheritting the wealth but woman has limited.

Women really live in a very harsh condition. They can not get real property, or even money from their parents. This atmosphere may create so many impact to womens' life or even to womens' image. At the time women can be intimidated by the other person who has a power. They have to follow what the other person command on them, they seem to be an obidience creature. On another side, there are also some women who being selfish, evil, arrogance, or even materialistic. Those womens' image depend on the existance of money and popularity. Thus primogeniture has born very big impact on womens's image at the time.

\section{Man's Existance in Threating Woman}

It is true that probably some of people think that in Austen's era, all of rich woman looks elegant and always being show off person in the society. In fact, Austen tries to 
speak out that there were still some other women who did not such those women who lived arrogantly and just want to respect others if they have firstly respected her. In any case, when woman tried to be nice infront of other people, man or exactly her husband did not respect her or even did not like her good attitude. It was reflected from the Palmer family story.

"Mrs. Palmer was several years younger than Lady Middleton, and totally unlike her in very respect. She was short and plump, had a very pretty face, and the finest expression of good humour in it that could possibly be. Her manner were by no means so elegant as her sister's,...”(Austen, 57)

Mrs. Charlotte Palmer is sister of Lady Middleton who seems so cheerful and is not similar as her sister. She is full of respects to others, eventhough sometime she do foolness but she is a good humour. Although she is a rich woman she cares the others and want to respect them in any situation they are.

"Well! what a delightful room this is! I never saw anything so charming! Only think, Mama, how it is improved since I was here last! I always thought it such a sweet place, ma'am! (turning to Mrs. Dashwood) but you have made it so charming! Only look, sister, how delightful every thing is! How I should like such a house for myself! Should not you, Mr. Palmer?" Mr. Palmer made her no answer, and did not even raise his eyes from the newspaper." (Austen,57)

Mrs. Jennings' younger daughter, Charlotte, is a foolish but cheerful young woman, strongly endowed by nature with a turn for being uniformly civil and happy. Short, plump, and pretty, she is not so elegant as her sister, Lady Middleton, but is much more prepossessing. When she visits the Dashwoods at Barton Cottage, she likes and admires everyone and everything. As stated in the quote aboves, that eventhough the cottage is small but she respects it and even admires it. She knows how to behave infront of lower-class people such as the Dashwood family life. The role that she does, is always respectable and even humbleness. When she tried to do good thing infront of other people, her husband does not support him. Mr. Parlmer is her husband who does not want to threat likeably his wife, although she is a good woman. Man does not care about woman no matter what. They are being ego and unrespectable person. they underestimate women

\section{The Image of Women n Society}

Daily life for women in the 19th century in England was that of many obligations and few choices. Some even compare the conditions of women in this time to a form of slavery. Women were completely controlled by the men in their lives. First, by their fathers, brothers and male relatives and finally by their husbands. Their primary purpose in life 
was to find a husband, reproduce and then spend the rest of their lives serving him. Chris William explains that;

In so doing, the acknowledged the important nineteenth century rethoric of separate spheres in establishing boundaries between the public and private worlds of the english middle class. While public life was increasingly seen as an exclusively male domain characterized by the manly virtues of action, determination, and resolution, the domestic setting was where woman's moral virtues of gentleness, tenderness, piety and faith could and should most fully be developed. (A Companion To 19th Century Britain,175)

The quotation above means that there was boundaries between man and woman in the public and private world in middle class. Man had more power, authority, and position in the society such as economic, politics, social power, educational and occupational. It can be brought up that man's domination is dominant rather than woman. In another side, women were expected to have a good virtues. Women had to be piety. It means that in everysituation women had to obey the rule. Their obligation was very important. Women had very limit right. Clearly they had the different treatment in society. This condition potrayed the situation of The Dashwood Women. Their image as women were to be piety. Contradictoryly with the upper class women, which live a little better live rather than a middle class women. They had money and wealth. They consequently possessed the independece and self-confidence to behave pretty much as they liked, eventhough it probably hurted someone else or being immoral women, such as being selfish, and being materialistic. The other sin of womens' image at the time was to be found out, not by theirs equals who gossiped freely about each other.

\section{Woman Was Being Submissive}

In England in 19th century almost all of women depended on the existance of money, heritage or even authority. Thats why if they had already married, they needed to obey man because in this case man held all of the authority including money or heritage. However, not all of men did not care about his family; whether his wife or even his daughters. In Sense And Sensibility Mr. Henry did really care about his family, he even asked his son to take care of them and make them comfortable before he finally dead. But the problem wass, while his son's wife; Fanny Dashwood who seemed so greedy which tried to control her husband and everything and let his family live sorrownessly.

"So acutely did Mrs. Dashwood feel this ungracious behavior, and so earnestly did she despise her daughter-in-law fo it, that, on the arrival of the latter, she would have quitted the house for ever...” (Austen,3)

Mrs. Dashwood as an example of a woman who had to let her happiness go because she had nothing anymore such as money or property. She and her three daughters had been 
lived in Norland for years, but she was able to surrender to the unfeeling circumstance, because all of the property and wealth is not given to her. She has to obey what her daughter in law command, eventhough its about leaving the house in Norland. "Many were the tears shed by them in thir last adieus to a place so much beloved." (Austen,19). Of course when we have to leave something which very meaningful to us, be ensure we will cry or be very sad. Painfull and dissapointment will be our part of feelings. In this novel we all know, when we have nowhere to live, we have to find other place to move at. This condition is what felt by Mrs. Dashwood and her three daughters. They have already nothing, so the only thing they can do is just go away and find a new life.

\section{Woman Was Being Selfish}

In fact, women were expected to remain subservient to their fathers and husbands. Their occupational choices were also extremely limited. Middle- and upper-class women generally remained home, caring for their children and running the household. Lower-class women often did work outside the home, but usually as poorly-paid domestic servants or laborers in factories and mills. On the other hand there were also some women who live better with their husband's money or wealth. They live so glamour and even they get rich cause of their husband heritance. However, woman who live with lots of money can be a good person and also a bad one.

"Mrs. John Dashwood now installed herself mistress of Norland; and her mother and sister in law were degraded to the condition of visitors..." (Austen,8)

The story talks about Fanny Dashwood as a wife of John Dashwood who played her roles selfishly. She had lots of money from her husband, and also from the bequet of her son. She wanted to take control all of the wealth in the Norland estate where her mother in law and also the three girls lived at. Eventhough they had lived there for years, Mrs. John Dashwood did not care about them, she installed them as visitors. It means that they have to move to another place. This story sums up that the authority of women or woman's status, sometimes make them to be blind and being selfish. The roles of this woman are just to intimidate the others rather than to help them.

\footnotetext{
"But, whatever might really be its limits, it was enough, when perceived by his sister, to make her uneasy, and at the same time,(which was still more common,) to make her uncivil. She took the first opportunity of affronting her mother in law on the occasion, talking to her so expressively of her brother's great expectations, of Mrs. Ferrar's resolution that both her sons should marray well.”(Austen 13)
}

Moreover, because of her capability in doing anything based on her wealth, Mrs. John Dashwood dared to talk to her mother in law rudely. She tried to convince her that her brother Edward will never be engaged with Elinor, because their mother wants him to 
marry someone at a good status as similar as her. There was no more respect to Mrs. John Dashwood's attitude while she spoke to her mother in law. It could be idetified that some women can not control their behaviors while they are almost being the first woman in her society. The role of woman such her is to take control all of the subsistance around her and even the circumstances at her society including her family. She was being selfish cause of the wealth the she had gathered with her husband.

\section{Woman Was Being Elegant}

In Austen era, the elegance of woman was quite important in the society. They will be respected more while their manner was kind of a perfect lady whether in style of dress or even in her bahavior. Some of them also looked like a kind lady infront of other people, although their kindness was not a sincerinity action. Such as Lady Middleton as wife of Mrs. Dashwood's cousin who pretend to be kind to help Mrs. Dashwood family, but in fact she was kind of a lady who just wanna show off her elegance.

"Lady Middleton had sent a very civil message by him, denoting her intention of waiting Mrs. Dashwood as soon as she could be assured that her visit would be no inconvenience; and as this message was answered by an invitation equally polite, her ladyship was introduced to them the next." (Austen 18)

The quotations above shows about Lady Middleton that in the beginning of her story which Austen tries to describe about her kindness for helping the Dashwood family, because her husband asks her to wait their coming. As a good wife, she has to obey what her husband said to her. This can tells us that woman also do their role based on what her husband want, eventhough she does not really want to do that. For instance, Lady Middleton who does her role as a wife just because of her husband.

"Lady Middleton piqued herself upon the elegance of her table, and of all her domestic arrangements; and from this kind of vanity was her greatest enjoyment in any of thir parties." (Austen 19)

Lady Middleton, in contrast to her husband, is perfectly well-bred but reserved and cold. She has few subjects of conversation and is concerned chiefly with the elegant maintenance of her household. In additional to proof her kindness, Lady Middleton arranged a beautiful-organized party at her house to celebrate the Dashwood family who just come to move at their new house in Borton. She gives her best sincerely to someone she should help. Lady Middleton once again tries to show the elegance of her family through the party. Actually the party is not really for the Dashwood family, but its just to show off her elegance infront of lots of people. It is usual if a rich woman likes to show off her elegance but to help people we can not use it as our kindness. 


\section{Woman Was Being Talented}

In Austen's era exactly in 19th century, it was very important for a girl or even a woman to be talented. They could be talented on singing or even in playing instrument or moreover in dancing. It was an age where the impact of the industrial revolution caused a sharp differentiation between the gender roles, especially of the upper and middle classes. Men were thought to have natures suited to the public world, women to the private. The following chart illustrates some of the differences that were thought to exist biologically. Woman is expected to be feminin such go for dance, singing, or generally woman was being talented to get a better life.

"He was a blessing to all the juvenile part of the neighbourhood, for in summer he was for ever forming parties to eat cold ham and chicken out of doors, and in winter his private balls were numerous enough for any young lady who was not suffering under the unsatiable appetite of fifteen.” (Austen, 21)

Sir John Middleton is a cousin of Mrs. Dashwood who has helped them to live in their small cottage at Barton village. At the time, to celebrate their coming, Sir John Middleton make a party who called Ball, where all of the woman especially young woman can attend that party to dance or even to find their soulmate. In England it is usual if woman goes to a party to get their love to their husband, because that is their custome at the time.

"In the evening, as Marianne was discovered to be musical, she was invited to play. The instrument was unlocked, everybody prepared to be charmed, and Marianne, who sang very well, at their request went the chief of the songs which Lady Middleto had brought into the family on her marriage." (Austen, 29)

The Victorian era seems like another world to us. Yet the late Victorians were very familiar with many of the things we use everyday. The one thing that was different was the place of women in society. There were of course perceptive women of independent original thought, but for the huge majority life was easier if they accepted that a woman's place was in the home. The accepted reasoning was that the career for women was marriage. In addition to being able to sing, play and instrument is what woman had being expected in Austen's era. Such as Marianne, who can sing well and also play piano, she was very talented at her age, thus many people liked her.

\section{Woman Was Being Independent-Mind}

It is not surprising that Jane Austen presents us with young heroines who are negotiating the business of courtship with varying levels of confidence and skill. She knew from first-hand experience how carefully a girl's behaviour would be observed by sharpeyed relations and other assessors, old and young, at social occasions. All these watchers 
would be keen to detect any sign of "loose morals" or vulgarity of style. She also knew that even exemplary manners, outstanding charm and dazzling beauty might not be enough to entice a suitor if the young lady's family background was not regarded as suitably wealthy or distinguished for his family. It all seems a daunting prospect compared with the apparent freedom young people enjoy today in their interactions with the opposite sex.

"Elinor, this eldest daughter, whose advice was so effectual, possessed a strength of undestanding, and coolness of judgment, which quilified her, though only nineteen, to be the conusellor of her mother, and enabled her frequently to counteract, to the advantage of them all, that eagerness of mind in Mrs. Dashwood which must generally have led to imprudence. She an excellent heart;-- her disposition was affectionate, and her feelings were strong; but she knew how to govern them:'(Austen 3)

Elinor is one of Austen's best characters who shows the reader that a woman should concern what Elinor did at her time. Elinor is a smart girl and very mature in thinking a way to solve or to face the problem. She care every members of her family, her sisters and her mother. She understands the situation and she knows how to act infront of people. She chooses to control her self to do what she really wants using her sense. She potrays a young independent girl at her time. In any situation, a young girl should be able to decide good thing to support her roles which be done in society. She need to be able to compare whether what she want or what she need. These two aspects sometimes produces painful in woman life, but Elinor can face that using her sense especially in doing her role around her era.

"Elinor had always thought it would be more prudent for them to settle at some distance from Norland, than immediately amongst their present acquaintance.” (Austen 16)

Elinor is not led by her emotions,. Instead of breaking down like her sister, she fulfill her obligation as a daughter, a sister, and a member of society, while trying to control the anguish of dissapointed condition. In most of her dealings with the outside world, Elinor represents the sense side of the equition. The quotations above tells us that Elinor is able to make a good decision for her goodness and her family life. She is clever to hide her sadness infront of her mother and sisters. She push herself to get out from Norland, eventhough there are lots of beautiful mesmories had been writen there. For the sake of her family she wants to leave everyhing she loves in Norland Park.

\section{Women Was Being Materialistic}

In Sense and Sensibility's story, materialistic is also one of womens' image at the time. All of aspect almost be influenced of materials such as money, property or even wealth. Women tend to do anything to get everything they want especially all about money. To be popular or even respected by the society, women has to live in a glamour life. Women is 
being materialistic caused everything will be esier for them to do. In this novel, there are many characters that show women in being materialistic.

"Mrs. Ferrars at first reasonably endeavoured to dissuade him from marrying Miss Dashwood, by every argument in her power;--told him, that in Miss Morton he would have a woman of higher rank and larger fortune;--and enforced the assertion, by observing that Miss Morton was the daughter of a nobleman with thirty thousand pounds, while Miss Dashwood was only the daughter of a private gentleman with no more than THREE."(Austen, 193)

Mrs. Ferrars is one of characters in Austen's novel that show the attitude of materialistic woman. She wants her elder son; Edward Ferrars should marry a woman with higher rank and with lots of wealth. Sho does not agree if he marry a women who has nothing in her life. Mrs. Ferrars is a rich women and she want her son to live with a rich woman either as rich as her. This character proofs that materialistic of women is one of image that has been created at the time.

"Edward was, of course, immediately convinced that nothing could have been more natural than Lucy's conduct, nor more self-evident than the motive of it."(Austen,190)

"The whole of Lucy's behaviour in the affair, and the prosperity which crowned it, therefore, may be held forth as a most encouraging instance of what an earnest, an unceasing attention to self-interest, however its progress may be apparently obstructed, will do in securing every advantage of fortune, with no other sacrifice than that of time and conscience."(Austen,194)

The quotations above explain about Lucy, one of character in Sense and Sensibility which also show that in the era of Austen's life, materialism was one of womens' image. Lucy enganged to Edward Ferrars because she knew that Edward was the elder son of Mrs. Ferrars who was going to inherit the wealth from his mother. The motive of her to marry him was just because of the imprudence of life. In the end of the story she married with Robert Ferrars because Edward won't get the wealth from his mother because he decided to marry Elinor; a woman that he really loved. Finally Robert married with Lucy and she can get what she want, she was being materialistic and married a man just because of the wealth.

\section{CONCLUSION}

During the Austin's era, women were viewed as the very opposite of what a man ought to be. The womens' image was brought up to believe that its ideal of character was the very opposite with mens' image, such as not self-will, and government by self-control, but submission, and yielding to the control of other, to live for others. Mostly women lived 
just to make complete abnegation of themselves, and to have no life but in their affections. Basically the womens' image were expected to be sweet, docile, innocent, virtuous, submissive, and man's perfect helpmate. Women were seen as pure and clean. Because of this view, their bodies were seen as temples which should not be adorned with jewelery nor used for physical exertion or pleasurable sex. The role of women was to have children and tend to the house, in contrast to men, according to the concept of Victorian masculinity.

In Sense And Sensibility, woman have to face unequal threatment on their life. They depend on man because in England, woman had very limit roles and also rights in the society and also in the family. The Primogeniture is one of causes that limited the roles and even the rights of women at the time. All the property or money had to be given to a son rather than to a daughter. It has created difficultiest circumstances to women to face the life. Kinds of athmosphere have formed to the women, whether rich women or poor women. In any case, there was few women that intimidated the other women cause of their status. As we know, wealth was valuable and meant a lot in this era, that is why rich woman behaves so unkindfull to other. They want to have everything whether popularity or even the wealth. But in fact, not all of rich women did bad thing to the poor women, because there was also woman who wanted to resperct the miner female. For miner's women, they tend to be submissivers while they had to follow the rule and do not have any chance to against it. Their choice is only to be strong to face the problem, or problably to be suffer caused of the problem.

\section{References}

Abrams, M.H. 1979. The Mirror and The Lamp: The Critical Tradition. USA; Oxford University, Press.

Austen Jane. 1811. Sense And Sensibility. London: Military Library.

Biography of Jane Austen. Retrieved January 15th, 2014 from http://www.jasa.au/jabiog. htm http://www.bbc.co.uk/history/historic_figures/austen_jane.shtml

Bodgan R and Biklen. 1982. Qualitative Research For Education, And Introduction to Theory and Metodhs 2nd Edition Boston. Allyn and Bacon, Inc.

Bressler, Charles.E. 1999. Literary Criticism: An Introduction to Theory and Practice Ed, USA, Pretice Hall Inc.

Das, P.K. 2002. Universal's Handbook On Hindu Succession: Property Right Of Women And Daughters. New Delhi, Law Publishing Co.

Ema McFoman (2014). The scandal of female miners in 19th-century Britain Retrieved February 23th,2014 from http://www.historyextra.com/feature/scandal-femaleminers-19th-century-britain 
Erickson, A. L. 2002. Women And Property: In Early Modern England. London, Prinnted Universe.

Griffith K. 1982. Writing Essays About Literature New Yesterday Harcount. Brace and Jovanvich, Inc.

Harwood, Natalie. 2006. Learning Latin Third Edition. Penguin Group, New York.

Helena Wotjtczak. Women's Status In Mid 19th-century England. Abrief overwiev. Retrieved January 1st, 2014 from http;/www.hastingspress.co.uk/history/19/overview.htm

Jamoussi, zouheir (1999). Primogeniture And Entailed In England. Retrieved January 13th, 2014 from www.c-s-p.org/flyers/978/1-4438-2864-2-simplepdf

Rheinstein M., and Glendon M.A.(1994-2002). Inheritance. Britanica 2002 duluxe edition cd-rom. Retrieved January 13th, 2014 from http;//britanica.com.inc.

William, Chris. 2008. A Companion To 19th Century Britain. USA, Blackwell Publishing.

19th Century England Social History. Retrieved January 5th,2014 from http;//www. victorianweb.org/history/class.html International Encyclopedia Of Marriage And Family (2003). Primogeniture. Retrieved January 15th, 2014 from http;//www.encyclopedia.com/topic/primogeniture.

Property Rights Of Women In Nineteenth Century England. Retrieved January 1st, 2014 from http;//www.123helpme.com/view.asp?id=18566

SparkNotes: Sense And Sensibility: Character List, themes. Retrieved January 5th, 2014 from http://www.sparknotes.com/lit/sensibility/section12.rhtml http:// www.sparknotes.com/lit/sensibility/characters.html http://www.cliffsnotes.com/ literature/s/sense-and-sensibility/critical-essays/plot-and-theme-in-sense-andsensibility

England Woman in 19th century. Retrieved February 23th, 2014 from http://www. teachushistory.org/detocqueville-visit-united-states/articles/early-19th-centuryattitudes-toward-women-their-roles

Gender In The Proceedings. Historical Backgroud. Retrieved February 2nd, 2014 from www.oldballeyonline.org/static/gender/jsp 